\title{
Analysis of Economic Transformation and Determination of Main Economic Sectors in the Future
}

\author{
Sri Lestari \\ Prodi Pendidikan Ekonomi \\ Fakultas Keguruan dan Ilmu Pendidikan \\ Universitas Islam Syekh-Yusuf Tangerang \\ srilestari28@student.upi.edu
}

\author{
Samsul Arifin \\ Jurusan Ilmu Ekonomi Pembangunan \\ Fakultas Ekonomi dan Bisnis \\ Universitas Sultan Ageng Tirtayasa \\ samsularifin@untirta.ac.id
}

\begin{abstract}
The objectives of this study are: the first, to demonstrate the economic relations between Jakarta-Banten and also National-Banten. The second is to identifying the main sector of economy in determining the future. Research methods were used to answer the first objective was the correlation of the product moment of economic growth. The second was based on figures LQ. The results showed the existence of a strong link between Banten-DKI Jakarta and National, both from the aspect of the similarity rate of economic growth as well as changes in economic transformation. There is a decrease in the role of a secondary sector particularly the processing industry and the tertiary sector showed potential as an option to support the economics of Banten ahead by looking at the condition of most of the tertiary sector sub with the growth trend of increased contributions to GDP. The Banten Government should develop the sector for having a high productivity without lowering the quality of the environment, land use and equitable development. Sectoral options are trade, hotel restaurant, and industry of transportation and communications. In the economics of Banten, the agricultural sector is not attractive but nationally, still relatively superior when agricultural developed in Banten Province compared to other provinces.
\end{abstract}

Keywords-Economic Growth, Sector Top / Base, LQ analysis.

\section{INTRODUCTION}

The development process is characterized by economic growth, followed by changes in the economic structure or the economic transformation that occurred in the economy nationwide, regional or local scale [1]. Structural changes in the economy occurred and focusing mechanism of economic transformation experienced by the developing countries that originally subsistence and focused on the agricultural sector to the modern sector of the economy dominated by industry and services sectors.

The process of economic transformation marked by the shift from agriculture to industry and then to services. The agricultural sector only becomes initial buffer when the transition processed, but subsequently the nonagricultural sector expands faster. Indonesia experienced a structural shift in the economy from agriculture to industry since the 1990s. The agricultural sector's contribution to Gross Domestic Product (GDP) National steadily declining due to a shift in the manufacturing sector accounted for a much greater contribution to GDP

In 1990 the agricultural sector accounted for 20.10 percent of GDP lower than in 1989 which amounted to 21.05 percent while the share of the industrial sector has reached 20.48 percent. A similar situation exists in the economy of Jakarta since the 2000s. Since 2001 the economy of Jakarta is dominated by Tertiary Sector activities with a share in excess of 70 percent of the GDP, the industrial sector amounted to 28.61 percent and the primary sector (agriculture) only by 0.16 percent

From the results of previous studies of the economic transformation process the occurence not only in Indonesia but also in Banten [2]. This required further research can be seen on the economic relationships that occured between BantenDKI Jakarta and Nationwide as well as determine the sector's flagship in the future.

The economic growth of a region affected by the three main components, namely the growth of national, sectoral growth, and the growth of regional competitiveness, Banten as a buffer economy of Jakarta the economic progress of Jakarta and economic progress in the National should be able to bring a positive impact on the economy of Banten became better and be seen through the image of the movement direction of the development of economic growth in Jakarta, National and Banten.

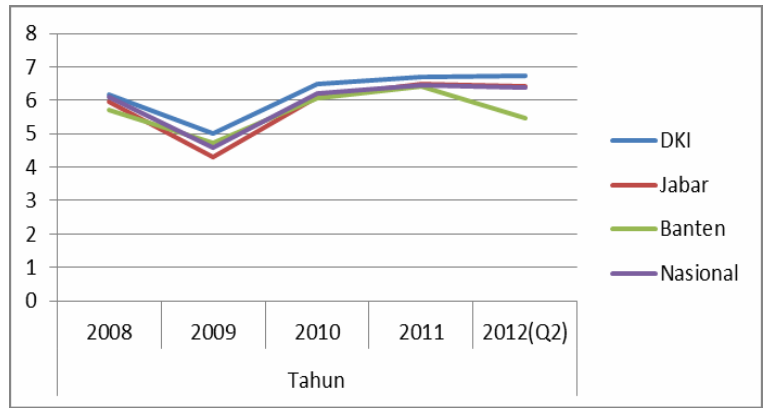

a. Sources: BPS Data processed

Fig. 1. Economic Growth Rate of Jakarta, West Java, Banten, and National (in percent) 
Economic growth rate DKI-Jakarta, Banten and National have the same trend is supposed success of national economic transformation and DKI-Jakarta followed by Banten's economy. Changes in the structure of the economy in Banten can bring economic and development approach Banten and DKI Jakarta with the national macro indicators, namely economic growth and income per capita. Comparison of per capita income and per capita income growth rate of Banten and DKI-Jakarta can be seen in the picture below.

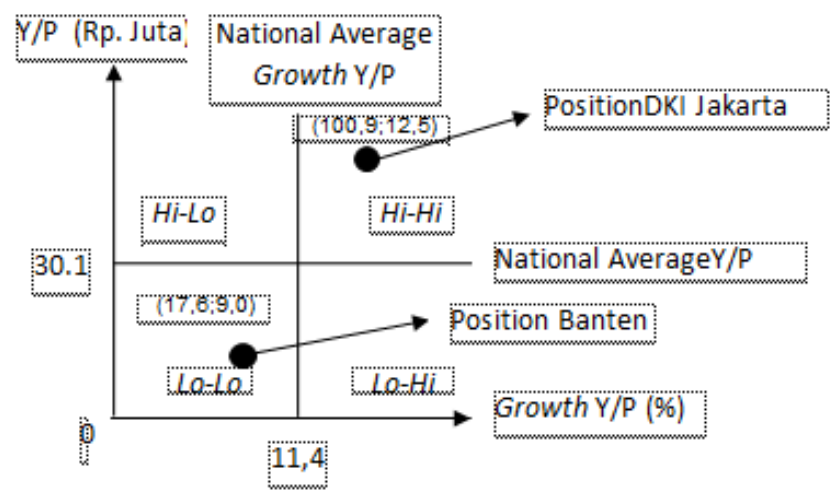

Fig. 2. Patterns Per Capita Income and Per Capita Income Growth Rate Banten and Jakarta against the National Average in the year 2011

Banten economy is still far below the national DKI-Jakarta and from the aspect of the amount of per capita income and the growth rate of per capita income and even economic growth.

- Is the economic transformation that occurred in the National and DKI-Jakarta, is followed by Banten economy by looking at the trend of change in the sectoral contribution?

- Is Banten economic sectors in the future must be built (the GDP indicators, employment indicators, and indicators of productivity) based on the Location Quotient?

The purpose of research is to see the relationship national economy, Banten and Jakarta, and linkages economy Banten as the buffer area economy of Jakarta and determine where and how development policy of Banten Province to the front as his position, to carry out a review of the major characteristics of economic development in Banten Province during this, the review will be conducted on the development of indicators of the GDP, employment, productivity, and population and the carrying capacity of the environment in the province of Banten.

\section{ECONOMIC GROWTH AND STRUCTURAL CHANGES}

Economic growth as a continuous rise in product per capita coupled with rising population and structural changes [3]. Economic growth shows how economic activity will generate additional income of the people in a given period. The indicators used to measure economic growth are the growth rate of Gross Domestic Product (GDP). The increase in GDP reflects the increased remuneration to the factors of production used in the production activity. In regional economics, the measure used to measure economic growth in the region is the Gross Domestic Product (GDP), the sum of gross value added (gross value added) generated by all sectors of the economy in the area.

While per capita income is the total income of the area which is divided by the total population for the same year [4]. Solow growth model formulates economic growth depends on the capital, labor and technology development. The model is formulated in terms of the function $Y=f(K, L, A)$ where $Y$ is output, $\mathrm{K}$ is capital, $\mathrm{L}$ is the labor force and $\mathrm{A}$ is the progress or development of technology. This model explains that economic growth depends on the factors of production.

The ability of local governments to look at the sectors which have advantages / weaknesses in the region is important. The sector that has the advantage, having better prospects for development and is expected to encourage other sectors to flourish. There are many theories that discussed related to regional economies / regions, such as Classical economic theory, Harrod- Domar, Solow-Swan, Base theories and models of interregional. There are several analytical tools that can be used to determine the relative potential of the economy of a region, such as Location Quotient (LQ).

Economic structural changes in the economy occurs and focuses on mechanisms of economic transformation experienced by the developing countries that originally subsistence and focused on the agricultural sector to the modern sector of the economy, which is dominated sectors of industry and services. Lewis, (1958) explains that the structural transformation of an economy occurs between the two sectors items, namely the traditional economic sectors (agriculture) and modern economic sectors (industry/capitalist) [3]. Chenery (1975) explains that the structural changes in the stages of the process of economic changes in developing country undergoing a transformation from traditional agriculture to switch to industry sector as the main engine of economic growth. Fei Theory, (1961) structural changes taking place with regard to the transfer of labor from agriculture to industry [3].

Activity in the regional economy can be classified in two activities namely base activity and non-activity basis. Base activities are the activities that make the activity of exportoriented goods and services out the boundaries of the economy. The larger the area the more advanced exports a growth area. Non-base activities are activities that provide goods and services needed by society residing within the borders of the economy. The broad scope of the production and marketing is local. The core of the economic model basis is that the direction and growth of an area will be determined by the sectors that export their products to the area or even to other countries [4].

\section{RESEARCH METHODOLOGY}

The paper discusses the research objects province of Banten, Jakarta and National related to macro data and secondary data used in the form of time series data (time series) the period of 2007-2011.

Related research for purposes of data analysis used some of the techniques of analysis, namely:

First, an analysis of the Correlation to find whether there is a relationship between economic growth in Banten-DKI Jakarta and Nationally used Product Moment Correlation. The next correlation coefficient calculation results can be interpreted through the coefficient of Rank Spearman [7]. 
Second, an analysis of the percentage of Contribution include:

1) Sectoral value added to GRDP to see the characteristics of the economy of a region can be based on the magnitude of the value added contribution of the respective sectoral against GRDP.

$$
\text { Sectoral contributions }=\frac{X i}{Y} x 100 \%
$$

$$
\mathrm{Xi}=\text { value added sector } \mathrm{Y}=\text { Total GRDP }
$$

2) Sectoral absorption of labor to total labor force to see the characteristics of the economy of a region can be based on the magnitude of the contribution of each sector (enterprises) in providing jobs.

$$
\text { Sectoral contributions }=\frac{X i}{Y} x 100 \%
$$

$$
\mathrm{Xi}=\text { value added sector } \mathrm{Y}=\text { Total of Labor }
$$

Third, the analysis of Figure Segregation Quotion (LQ) to know the relative level of excellence of a sector in a region against the sector in other areas within a country. In the calculation basis of the LQ was based on labor, and GRDP. Technical analysis is used to identify a local sector basis is the theory of location quotients (Location Quotient). The indicators used for this technique is employment, the GDP of a region or commodity. LQ index is the ratio between the number of workers in a particular sector or sectors to the total value of GDP of labor across sectors or the total GDP in the region as compared to the ratio of the value of labor-sectoral or sectoral GDP in the same sector of the economy or national referenced.

Figures Location Quotient (LQ) performed at the relative merits of a sector in an area of the sector in other regions within a country. Figures LQ is generally used to determine the basic sector of an area. This LQ Score ranges from 0 to positive infinity. Figures LQ of less than 1 indicates that the sector in question no longer has a relative advantage. When the LQ figure is equal to 1 , then the sector has the advantage of relatively similar to the average of all regions. While Figures LQ greater than 1 indicates that the sector has the advantage of relatively higher than average. In calculating the LQ based on the basis of labor, the GRDP, and commodity / production.

$$
L Q=\frac{X_{i j} / X_{j}}{Y_{i} / Y}
$$

Justification for the analytical techniques LQ on the basis of employment by sector is as follows: 1) if LQ > 1 then a sector is said to be a sector basis, 2) if $L Q=1$ then a sector is said to be a sector basis, and 3) if LQ $<1$ then a sector is not said a sector basis

\section{RESULTS AND DISCUSSION}

Research results related to the first, an overview of the State of economic development/relationship between the BantenDKI and National indicators of the correlation coefficient are shown by the rate of economic growth.
TABLE I. THE VALUE OF THE CORRELATION COEFFICIENT (R) PRODUCTS MOMENTS

\begin{tabular}{|l|l|lc|}
\hline & \multicolumn{1}{|c|}{ Banten-DKI } & Banten-Nasional \\
\hline Nilai R & 0.96 & 0.91 & \\
\hline \multicolumn{2}{|c|}{${ }^{\text {a. }}$ Source: the data processed }
\end{tabular}

Based on the value of the correlation coefficient product moment, the relationship of Banten-DKI Jakarta also National at level relations are on a very tight/strong. The interpretation of this result means that the rate of economic growth between regions (Banten, Banten, Jakarta-national) there is a very strong relationship. The occurrence rate of economic growth in Banten is very powerful relationship with the rate of economic growth in JAVA, as well as the rate of economic growth of Java is also very strong relationship with the national economic growth rate

- The economic transformation that occurred in the

\begin{tabular}{|c|c|c|c|}
\hline No. & Indikator & Banten & DKI Jakarta \\
\hline 1 & $\begin{array}{l}\text { Sectoral } \\
\text { growth }\end{array}$ & $\begin{array}{l}\text { Most of the tertiary sub- } \\
\text { sector has had a positive } \\
\text { growth rate increasing } \\
\text { trend. }\end{array}$ & $\begin{array}{l}\text { All sectors of } \\
\text { the } \\
\text { Tertiary have had a } \\
\text { positive growth rate }\end{array}$ \\
\hline 2 & $\begin{array}{l}\text { Sectoral } \\
\text { contributions }\end{array}$ & $\begin{array}{l}\text { Nearly } 50 \text { percent of } \\
\text { GDP contributed by tertiary } \\
\text { sector contribution }\end{array}$ & \begin{tabular}{|lr}
$0 \quad$ percent & of \\
GRDP & \\
contributed & by \\
tertiary & sector
\end{tabular} \\
\hline 3 & $\begin{array}{l}\text { Relative } \\
\text { superiority } \\
\text { GRDP) }\end{array}$ & $\begin{array}{l}\text { Business Field that is part } \\
\text { of Secondary and Tertiary } \\
\text { Sector is no longer the } \\
\text { primary sector }\end{array}$ & $\begin{array}{r}\text { Tertiary sector } \\
\text { is } \\
\text { characterized } \\
\text { by }\end{array}$ \\
\hline 4 & $\begin{array}{l}\text { Relative } \\
\text { superiority (LQ } \\
\text { employment) }\end{array}$ & $\begin{array}{l}\text { Secondary sector } \\
\text { (Manufacturing) is still the } \\
\text { sector with the main base } \\
\text { in the crutch by } \\
\text { Tertiary sector }\end{array}$ & Tertiary sector \\
\hline 5 & $\begin{array}{l}\text { Relative } \\
\text { superiority (LQ } \\
\text { productivity) }\end{array}$ & $\begin{array}{l}\text { Secondary and tertiary } \\
\text { sectors are less than 1, the } \\
\text { primary sector (agriculture) } \\
\text { is greater than one with a } \\
\text { tendency to increase }\end{array}$ & $\begin{array}{l}\text { Tertiary sector } \\
\text { is } \\
\text { much larger than } \\
\text { the primary and } \\
\text { secondary sectors }\end{array}$ \\
\hline
\end{tabular}
National and DKI Jakarta, Banten is followed by the economy based on the results of research by looking at the trend of changes in the sectoral contribution.

TABLE II. INDICATORS OF ECONOMIC STRUCTURALCHANGE BANTEN AND JAKARTA

Economic transformation occurred in Jakarta and Banten. Changes in economic structure that occurred in Jakarta are more noticeable shift from the primary sector to the secondary sector of the economy has become even tertiary structure.

The above findings reinforce previous research results that States internally in Banten's economy is undergoing economic transformation, within the last 20 years the economy of the province of Banten is one of 10 other provinces already resting on the manufacturing sector, trade sector-hotel-restaurant, the service sector, and sectors including building is DKI Jakarta [5] and the results of other studies that support the opinions above that the economic structures of Banten is dominated by trade sector, the industrial sector and the financial sector \& services [6] 
- The economic sector of Banten province in the future must be built to conduct a review of the state of the economy of Banten province on the development of indicators of the GRDP, employment, productivity.

\section{A. Indicators Gross Regional Domestic Product (GRDP).}

Banten Province had experienced negative growth in the crisis period of 2008 - 2009, and since 2010 and 2011 the economy returned to positive growth with a tendency to increase approaching the situation as it was before the crisis which in 2007 amounted to $6.04 \%$.

From a number of sub-sectors, Industrial Finance, Real Estate Building \& Business Services have the growth rate of the average per year is the highest during the last five years (11:32 per cent), followed second by Business Sector Mining and Quarrying (10.67 percent) and third is the Business Sector Transportation and Communications (9.64 percent). In general, sees the growth rate of the average secondary sector (Manufacturing; Electricity, Gas and Water, as well as building/construction) and tertiary (Trade, Hotels and Restaurants; Transport and Communications; Finance, Leasing Building and Service Company, as well as Services otherservices) in the same direction.

The interesting is Industrial Transportation \& Communications in addition to occupy the third position is also consistent growth rate has a positive growth during the five year period (2007-2011). Industrial Manufacturing is a business field with the greatest value added contribution to the GDP; which is about $46.91 \%$ the GDP on average over the past five years.

Industrial added value of the next largest contributor in a row is a field of Trade, Hotels and Restaurants; Industrial Transportation \& Communications occupied third position in contributing to the value added to the GDP; and Agriculture. It means that during this economy, Banten Province has undergone a change from primary to secondary sector to the tertiary sector, which is supported by the presence of indicators of the increasing contribution of value-added sub-sectors across the secondary during the last five years have approached 50 percent of the GDP. But the contribution of secondary sector has continued to decline in line decline in Industrial Processing Industry as the biggest contributor in the secondary sector $(86 \%)$.

Figures LQ based Real GRDP data for each sector (activities) in Banten province during the period 2007-2011, the economic sector in Banten Province has an advantage relative to other regions is partly Business Field that is part of Secondary and Tertiary Sector is no longer the primary sector (agriculture). It is based on LQ Figures Sectors> 1. In more detail, Industrial Electricity, Gas \& Water in Banten Province have the highest LQ digits, so they are business field highest relative advantage. Then followed by Business Sector Processing Industry; Trade, Hotels and Restaurants. Industrial Transportation \& Communication are ones of the main parts of the basis for the economy sector of Banten.

Interestingly, since 2001 (the initial stands Banten province) Business Sector which has the digits LQ $>1$ is the fourth Business Sectors (Electricity, Gas, \& Water as a minimum; Manufacturing; Trade, Hotels \& Restaurants; and Transport \& Communications) even though having a trend that continues to decline. Meanwhile, the Primary Sector and the four other key industries sector are not basis for Banten province, which is shown by Figures LQ $<1$.

Banten is not the economy of agriculture (primary sector), Banten's economy has been transformed into a secondary sector of the economy. Within the last five years showed that the Industrial Manufacturing as the largest contributor to the GDP contribution of the secondary sector has been experiencing a slowdown Banten, both from the aspect of growth and contribution. It is interesting that the tertiary sector provides an alternative choice as a Business Field potentially forward to support the economy of Banten (the majority of subtrend growth in the tertiary sector has improved with the contribution to the GDP is increasing and has a relative advantage compared to other areas).

\section{B. Indicators of Labor Absorption}

Banten province's economy on the development of employment indicators are based on five Main Business Fields Banten province, namely Agriculture, Manufacturing, Trade, Hotels \& Restaurants, Service and others. Year 2007-2011, Fields of Trade, Hotel and Restaurant are business field Tertiary Sector greatest contribution in absorbing labor in Banten Province. While the Business Field Agriculture, although it has a contribution in the third-largest labor absorption an average of about 18 percent of the total workforce in Banten province, it has a continuous down trend.

LQ Figures could also be applied to the Labor Absorption indicator to determine the basic sector in Banten province, particularly with regard to the contribution of each sector (activities) in absorbing labor. Farming had digits LQ very small (close to 0). That means Manpower Absorption LQ Figures; Primary Sector is not a basis for the province of Banten.

Secondary Sector Figures LQ $>1$, the secondary sector is still rated as one of the basis sector in Banten province, such as Industrial Manufacturing. Interestingly, many business field Tertiary sector (sector which is characterized by services) $>1$. What is striking, when the four main business fields more affected by the crisis of 2008 occured the downward trend in both contribution and LQ but not for Industrial Manufacturing continued to trend improved growth. Based on the relative contribution and excellence in employment, Secondary Sector (Manufacturing) is still the sector with the main base in the crutch by Tertiary sector is the mainstay of future sector basis in Banten Province.

\section{Productivity Indicators}

Figures LQ productivity (labor) of each sectors (activities) in Banten province, seen almost all the numbers LQ Productivity Secondary and Tertiary sector $<1$, except primary sector (agriculture) $>1$ with a tendency to increase. Industrial Manufacturing originally had a figure LQ Productivity $>1$ turns into digits LQ Productivity $<1$ with the amount continues to decline, while the figure LQ Productivity Business Sector Trade, Hotels \& Restaurants were $<1$ by the amount of close to 1 is different from the figure LQ Productivity Business Sector the services that are $<1$ with a magnitude far from one.

- Business Field Agriculture still has the advantage of productivity compared to productivity in other areas and still allows it to return more developed in Banten 
province forward to improvements in business field coupled Processing Industry and Trade, Hotels \& Restaurants. Primary sector (Agriculture) it can be said still serves as one of the basic sector in Banten province, when the judgment is based only on Productivity Indicators. However, when consideration is also included other indicators (GDP and Labor Absorption), then the Primary Sector cannot be used as the basic sector that will be developed in the construction of Banten province forward.

\section{CONCLUSION \& SugGeSTIONS}

Economic transformation that occurred in the National and Jakarta also occurred in the economy. A decline in the role of Sector Secondary particularly sub-sector Business Sector Industry Processed and showed how prospective Sector Tertiary as an alternative choice as a Business Field potentially forward to support the economy of Banten when the majority of the sub-sector tertiary growth trend improved with the contribution to the GRDP is increasing and has an edge relative.

These findings provide a strong argument for Banten to start thinking of alternative election Tertiary sector as the sector that should be developed in Banten province in the future, especially Field of Trade, Hotel, Restaurant; Industrial and Transportation and Communication. So in the future, the economic development of Banten province should be directed to sectors with high productivity. Banten agricultural sector in the economy is not to be interesting but still leads the National relative when the agricultural sector developed significantly in the province of Banten.

Economic transformation that occurred in the National and Jakarta also followed by Banten's economy, there is a link between the state of the economy in Banten to Jakarta and Manila. The development process in the province of Banten not only on the state of internal but also external economies associated in surrounding area, especially Jakarta and Manila.
So, the economic policies in Banten must pay attention to the internal and external economic developments.

A decline in the role of secondary sector in particular subsector Business Sector Industry Processed and looks prospective Tertiary sector as an alternative choice as a Business Field potentially forward to support the economy of Banten. These findings require the Field of Trade, Hotel Restaurant; Industrial and Transportation and Communications have the support of local government policy.

\section{REFERENCES}

[1] Todaro, M.P. and Smith S, "Pembangunan Ekonomi di Dunia Ketiga", Jakarta: Erlangga, 2008, p21

[2] Samsul Arifin, "Identifikasi Sektor Utama Perekonomian Banten di Masa Depan”, Laporan PDP, Untirta, 2013, p19

[3] Jhingan, M.L, "Ekonomi Pembangunan dan Perencanaan", Jakarta: PT Raja Grafindo Persada, 2007, pp67

[4] Tarigan, Robinson. Perencanaan Pembangunan Wilayah. Jakarta: Bumi Aksara, 2007, p55

[5] Sitanggang, Nachrowi , "Pengaruh Struktur Ekonomi pada Penyerapan Tenaga Kerja Sektoral: Analisis Model Demometrik di 30. Propinsi pada 9 Sektor di Indonesia”, JEPI. Vol 5, No 1. 2004, p 1

[6] Sayifullah dan Sugeng S, "Analisis Struktur Ekonomi dan Spesialiasi Sektor Ekonomi Provinsi Banten”, Perpustakaan Universitas Sultan Ageng Tirtayasa, 2011, pp 18

[7] Sugiyono, Metode penelitian pendidikan, Alfabeta , Bandung, 2009, pp 228

[8] Bank Indonesia, (2009), Kajian Ekonomi Regional, Triwulan I-IV 2009

[9] Bank Indonesia, (2009), Kajian Ekonomi Regional, Triwulan I-IV 2009

[10] Badan Pusat Statistik Provinsi Banten, (2008), "Banten Dalam Angka", Provinsi Banten

[11] Badan Pusat Statistik Provinsi Banten, (2009), "Banten Dalam Angka", Provinsi Banten

[12] Badan Pusat Statistik Provinsi Banten, (2010), "Banten Dalam Angka", Provinsi Banten

[13] Badan Pusat Statistik Provinsi Banten, (2011), "Banten Dalam Angka", Provinsi Banten

[14] Badan Pusat Statistik Provinsi Banten, (2012), "Banten Dalam Angka", Provinsi Banten 